\title{
Midregional proatrial natriuretic peptide improves risk stratification after ischemic stroke: Association with mortality and cardioembolic etiology
}

Neurology ${ }^{\circledR}$ 2018;91:637. doi:10.1212/WNL.0000000000005190

In the article "Midregional proatrial natriuretic peptide improves risk stratification after ischemic stroke: Association with mortality and cardioembolic etiology" by G.M. De Marchis et al., ${ }^{1}$ the version published ahead of print on January 10, 2018, contained some errors. The sixth sentence of the Abstract should specify “continuous net reclassification index (cNRI)," and the ninth sentence should report the significance of $c$ NRI of atrial fibrillation at $(78 \%, 95 \% \mathrm{CI}$ $60 \%-89 \%, p<0.001)$. In the Results section, the third sentence has been changed to "The median age of the cohort was 71 (IQR 61-80) years, and 298 (38\%) were women." Under the subsection "Prediction of functional outcome after 3 months," the first sentence of the second paragraph should report "(AUC change from 0.85 [95\% CI 0.83-0.88] to 0.86 [95\% CI $0.83-0.88], p<0.0071)$." The last sentence of the Results section should specify ".... continuous NRI of 78\%." The title for table 2 should read, "Multivariate logistic and Cox regression analyses for 90-day functional outcome and mortality WITH and WITHOUT MR-proANP." In table 4 , the number (n) and percentage (\%) values were reversed from row 3 through row 12, and in table 5, row 7 should have a $p$ value of 0.35 (for dyslipidemia), rather than 0.035 as originally published. Corrected text and tables were published in the final version on February 6 , 2018. The authors regret the errors.

\section{Reference}

1. De Marchis GM, Schneider J, Weck A, et al. Midregional proatrial natriuretic peptide improves risk stratification after ischemic stroke: association with mortality and cardioembolic etiology. Neurology 2018;90:e455-e465.

\section{Eteplirsen treatment for Duchenne muscular dystrophy: Exon skipping and dystrophin production}

Neurology ${ }^{\circledR}$ 2018;91:637. doi:10.1212/WNL.0000000000005979

In the article "Eteplirsen treatment for Duchenne muscular dystrophy: Exon skipping and dystrophin production" by J.S. Charleston et al., ${ }^{1}$ the Acknowledgment is incomplete. It should also include "The authors also gratefully acknowledge Dr. Steven A. Moore, the University of Iowa Hospitals and Clinics Histology Laboratory, and the Iowa Wellstone Muscular Dystrophy Cooperative Research Center (NIH grant U54, NS053672) for providing frozen sections of non-dystrophic control muscle biopsies, Becker muscular dystrophy muscle biopsies, and untreated DMD biopsy samples from the PROMOVI clinical study described in this manuscript. Dr. Moore also assisted in establishing criteria for defining dystrophin positive muscle fibers." The authors regret the omission.

\section{Reference}

1. Charleston JS, Schnell FJ, Dworzak J, et al. Eteplirsen treatment for Duchenne muscular dystrophy: exon skipping and dystrophin production. Neurology 2018;90:e2146-e2154. 


\title{
Neurology
}

\section{Eteplirsen treatment for Duchenne muscular dystrophy: Exon skipping and dystrophin production \\ Neurology 2018;91;637 \\ DOI 10.1212/WNL.0000000000005979}

This information is current as of September 24, 2018

\author{
Updated Information \& \\ Services \\ including high resolution figures, can be found at: \\ http://n.neurology.org/content/91/13/637.2.full \\ References \\ This article cites 1 articles, 1 of which you can access for free at: \\ http://n.neurology.org/content/91/13/637.2.full\#ref-list-1 \\ Permissions \& Licensing \\ Information about reproducing this article in parts (figures,tables) or in \\ its entirety can be found online at: \\ http://www.neurology.org/about/about_the_journal\#permissions \\ Reprints \\ Information about ordering reprints can be found online: \\ http://n.neurology.org/subscribers/advertise
}

Neurology ${ }^{\circledR}$ is the official journal of the American Academy of Neurology. Published continuously since 1951, it is now a weekly with 48 issues per year. Copyright (O) 2018 American Academy of Neurology. All rights reserved. Print ISSN: 0028-3878. Online ISSN: 1526-632X.

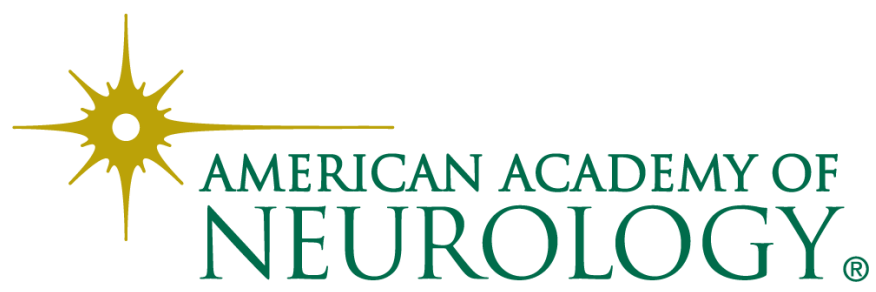

